\title{
ПЕРМСКИЕ МОРСКИЕ ФАЦИИ ВОСТОЧНОЙ ПЕРИФЕРИИ ОХОТСКОГО СЕДИМЕНТАЦИОННОГО БАССЕЙНА (Северо-Восток Азии)
}

\author{
А. С. Бяков ${ }^{1,2}$, И. Л. Ведерников ${ }^{1}$ \\ ${ }^{I}$ ФББУН Северо-Восточный комплексный научно-исследовательский институт \\ им. Н. А. Шило ДВО РАН, г. Магадан \\ ${ }^{2}$ ФГБОУВО «Северо-Восточный государственный университет», г. Магадан \\ E-mail: abiakov@mail.ru
}

\begin{abstract}
В разрезе пермских отложений восточной периферии Охотского седиментационного бассейна (Северо-Восток Азии) установлены пять основных групп фаций: прибрежных песчаников, песчаников и алевролитов внутренней части шельфа, алевролитов внешней части шельфа, турбидитов и потоков разжиженного осадочного материала. Группа фаций турбидитов подразделена на фации проксимальных (песчаниковых) и дистальных (глинистых) турбидитов. Группа фаций потоков разжиженного осадочного материала разделена на фации грейнитов, дебритов и собственно глинистых потоков. Первые группы фаций характеризуют относительно мелководные (шельфовые) обстановки осадконакопления, в то время как последние две отвечают более глубоководным обстановкам континентального склона и его подножия. Приведены фотографии наиболее типичных текстур.
\end{abstract}

\section{Ключевые слова: фации, восточная периферия Охотского седиментационного бассейна, пермь, Северо-Восток Азии.}

DOI: 10.34078/1814-0998-2019-4-18-28

\section{ВВЕДЕНИЕ}

Охотский седиментационный бассейн выделяется в пределах одноименного массива (террейна) и его обрамления, расположенного в юго-восточной части Яно-Колымской складчатой системы. Бассейн имеет двойственную тектоническую природу: с одной стороны, он является задуговым по отношению к реконструируемой нами Охотско-Тайгоносской вулканической дуге, а с другой - отчасти связан с Верхоянским окраинно-эпиконтинентальным морем (Бяков и др., 2005, 2017) - рис. 1. Сведения о пермских породах Охотского бассейна, играющих в его строении определяющую роль, все еще остаются весьма отрывочными в силу их слабой изученности, поэтому представляется важным изучение различных их характеристик, которые необходимы при проведении литолого-фациального анализа.

Для рассматриваемого бассейна характерны как континентальные, так и морские мелководные отложения со значительной долей вулканитов различного состава, в том числе и лав (Умитбаев, 1963). По восточной периферии бассейна фиксируются глубоководные фации континен-

(С Бяков А. С., Ведерников И. Л., 2019 тального склона, представленные мощными (до 6 км) толщами различных гравититов (в основном турбидитов и диамиктитов). Нами изучены, главным образом, эти глубоководные фации, а также основные группы мелководных морских фаций (Бяков, Ведерников, 1990; Бяков, 2001, 2007).

\section{ОПИСАНИЕ ФАЦИЙ}

Используя методологический подход О. В. Япаскурта (1992), предложившего, на наш взгляд, удачную методику фациального анализа мощных, сложно построенных толщ на примере верхоянского комплекса (верхний палеозой - средний мезозой пассивной окраины Северо-Азиатского кратона), среди изученных пермских отложений Охотского седиментационного бассейна мы выделили следующие основные группы морских фаций: 1) прибрежные песчаники; 2) песчаники и алевролиты внутренней части шельфа; 3 ) алевролиты внешней части шельфа; 4) турбидиты (дистальные и проксимальные) и 5) потоки разжиженного осадочного материала (грейниты, дебриты и собственно глинистые потоки). Каждая из выделенных групп фаций по рангу обычно соответствует свите или, реже, подсвите. 


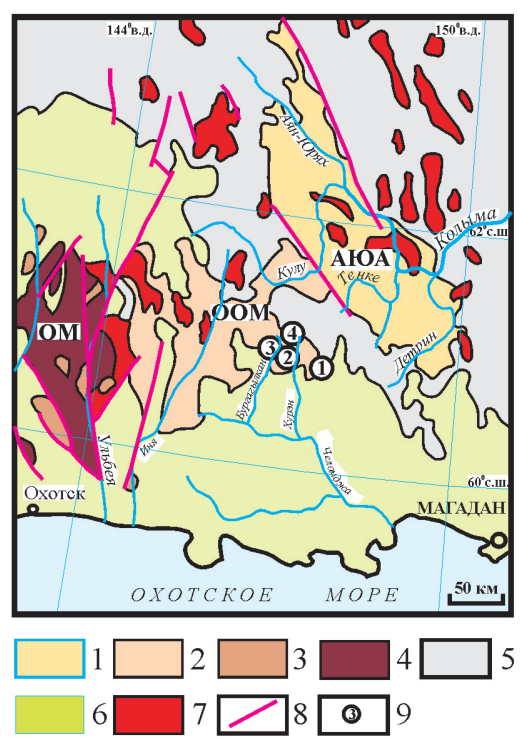

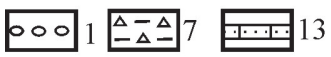

$2 . .12$ 드응 8

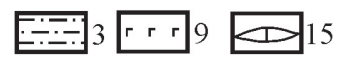

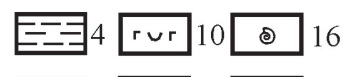

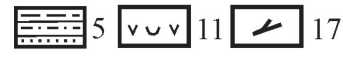

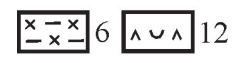

1. Руч. Пластовый

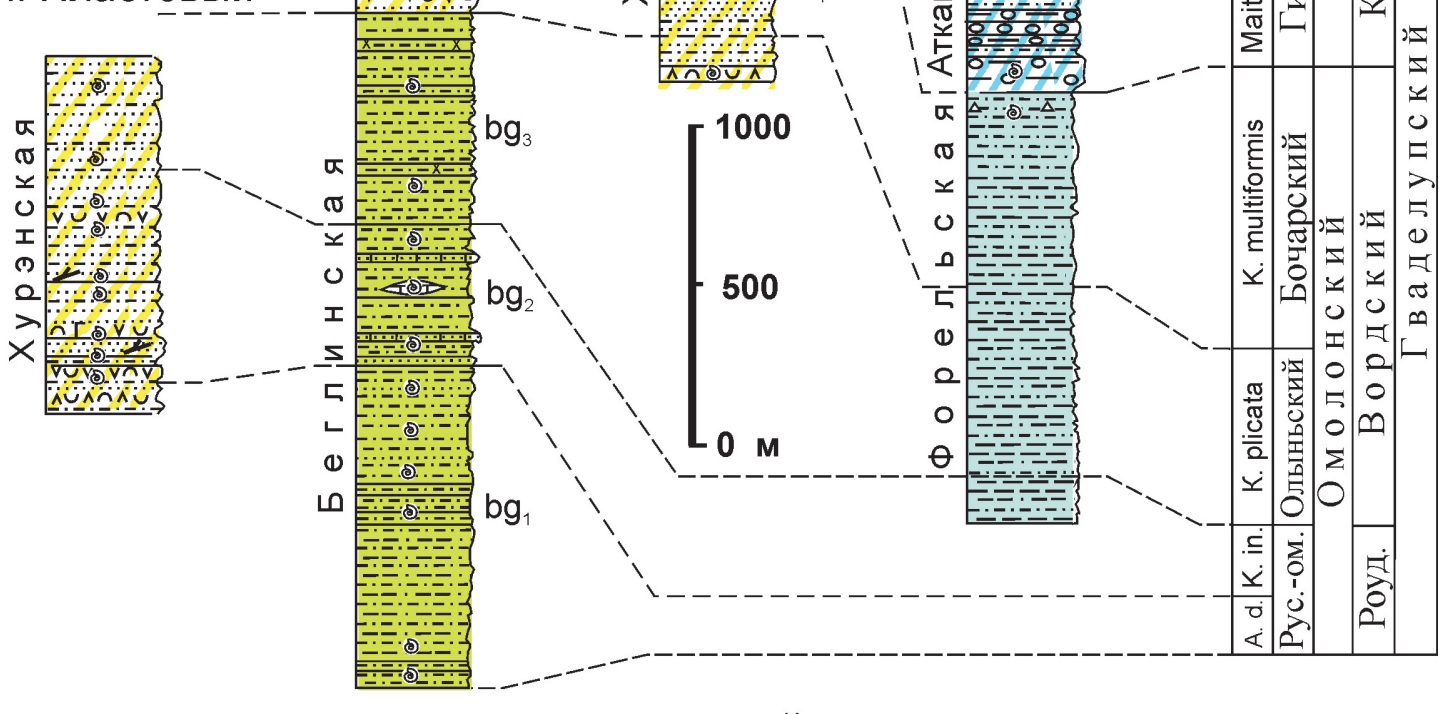

ГРУППЫ ФАЦИЙ:

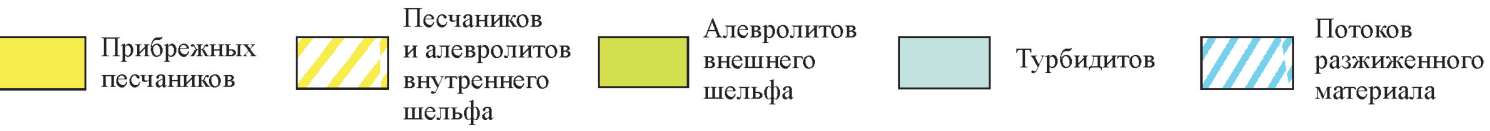

Рuc. 1. Схема расположения изученных разрезов, их сопоставление (по: Бяков, 2007; Davydov et al., 2018) и выделенные группы фаций в перми Охотского бассейна: 1 - гравелиты, конгломераты и грубозернистые песчаники; 2 - песчаники; 3 - алевролиты; 4 - аргиллиты; 5 - турбидиты; 6 - рассеянный в породах материал песчаной размерности; 7 - диамиктиты с рассеянным материалом песчаной и гравийной размерности; 8 - диамиктиты с рассеянным материалом гравийной и галечной размерности; 9 - лавы базальтов; 10 - туфы основного состава; 11 - туфы среднего состава; 12 - туфы кислого состава; 13 - песчанистые известняки; 14 - линзы гравелитов и конгломератов; 15 - линзы известняков; 16 - остатки ископаемой фауны; 17 - углефицирован- 
ные растительные остатки. Аббревиатуры: РСШ - Региональная стратиграфическая шкала пермской системы; МСШ - Международная стратиграфическая шкала. А. d. - Aphanaia dilatata; K. in. - Kolymia inoceramiformis. Ha врезке: 1-3 - пермские отложения: в пределах Аян-Юряхского антиклинория (1), обрамления Охотского массива (2) и собственно Охотского массива (3); 4 - до- и послепермские образования Охотского массива; 5 - триасовые и юрские отложения за пределами Охотского массива; 6 - вулкано-плутонические комплексы ОхотскоЧукотского вулканического пояса; 7 - гранитоиды; 8 - основные разломы; 9 - изученные разрезы в пределах восточного обрамления Охотского массива, АЮА - Аян-Юряхский антиклинорий, ОМ - Охотский массив, ООМ - обрамление Охотского массива

Fig. 1. Location of studied sections, their correlation (after Biakov, 2007; Davydov et al., 2018), and the established facies in the Okhotsk basin Permian: 1 - gravelites, conglomerates, and coarse-grained sandstones; 2 - sandstones; 3 siltstones; 4 - mudstones; 5 - turbidites; 6 - sand-size material dispersed in rocks; 7 - diamictite with dispersed sandand gravel-sized material; 8 - diamictite with dispersed gravel- and pebble-size material; 9 - basaltic lavas; 10 - basic tuffs; 11 - intermediate tuffs; 12 - acid tuff; 13 - sandy limestones; 14 - gravelstone and conglomerate lenses; 15 - limestone lenses; 16 - fossil fauna remains; 17 - coalified plant remains. Abbreviations: PCW - Regional stratigraphic scale of the Permian; MCШ - International stratigraphic scale. A. d. - Aphanaia dilatata; K. in. - Kolymia inoceramiformis. Inset: 1-3 - Permian deposits: within the Ayan-Yuryakh anticlinorium (1), the Okhotsk massif framing (2), and the Okhotsk massif proper (3); 4 - pre- and post-Permian deposits of the Okhotsk massif; 5 - Triassic and Jurassic deposits outside the Okhotsk massif; 6 - volcano-plutonic complexes of the Okhotsk-Chukchi volcanic belt; 7 - granitoids; 8 - faults; 9 - studied sections within the eastern framing of the Okhotsk massif, AЮA - Ayan-Yuryakh anticlinorium, OM - Okhotsk massif, OOM - framing of the Okhotsk massif

Первые три группы фаций характеризуют мелководные (шельфовые), а остальные две глубоководные обстановки континентального склона и его подножия. Мелководным группам фаций свойственны все признаки относительного мелководья: преимущественно песчаный и более грубый состав пород, соответствующий набор текстур, углефицированные растительные остатки, прослои ракушечников, сложенных преимущественно раковинами двустворчатых моллюсков. Глубоководные группы фаций характеризуются обычно более тонкой гранулометрией, часто встречается градационная слоистость, иногда наблюдаются подводно-оползневые текстуры, остатки фауны гораздо более редки.

Группа фаций прибрежных песчаников характерна для кулинской свиты восточной периферии Охотского бассейна. Типичные породы песчаники серые и светло-серые, часто с зеленоватым оттенком, чаще массивные или ясно- и неяснопятнистые за счет интракластов темносерых аргиллитов, нарушенных ходами илоедов и динамикой среды осадконакопления (рис. 2, $\partial-$ ж). Реже наблюдаются тонкогоризонтальнослоистые и слабо косослоистые песчаники (рис. 2, 2), обычно плохо сортированные, полевошпатоволититовые. Размерность зерен колеблется от мелко- и среднезернистых до крупно- и грубозернистых. Характерные текстуры - обратная градационная слоистость, наблюдаемая в пачках мощностью до 10 м за счет огрубления материа- ла от подошвы слоя к кровле, нечеткая горизонтальная слоистость и пятнистость пород. Нередки неопределимые углефицированные растительные остатки, обычно пиритизированные, и более мелкий растительный детрит. Присутствуют известковистые стяжения шаровидной формы диаметром 10-15 см (рис. 2, в) и отдельные интракласты темно-серых аргиллитов (рис. 2, з).

Для этой породной ассоциации характерны также слои и пачки гравелитов и мелкогалечных конгломератов (до 20 м). Наблюдаются прослои, пакеты и отдельные пачки (до 2-6 м) алевролитов с единичными желваками сульфидов (от 1 мм до 5 см в диаметре) и алевролитов углистоглинистых с прослоями (от 1 мм до 1-3 см) черных аргиллитов. По всему разрезу присутствуют слои витро- и литокристаллокластических туфов и туффитов различного состава.

В целом эта группа фаций отражает следующую последовательность изменения мелководных обстановок, выявленную с использованием методологических разработок Р. К. Селли (1989): 1) песчаники (барьерный остров); 2) алевролиты (нормальное море); 3) аргиллиты и песчаники (лагуны и приливно-отливная отмель).

Нередко в больших количествах встречаются остатки фауны (в этом случае они обычно однообразны по систематическому составу) и образуют ракушечники (рис. 2, a), сложенные двустворчатыми моллюсками родов Intomodesma (рис. 2, б) и Maitaia.

Puc. 2. Типовые текстуры группы фаций прибрежных песчаников, кулинская свита: $a$ - ракушечник, сложенный обломками раковин иноцерамоподобных двустворок; $\sigma$ - отпечаток гигантской иноцерамоподобной двустворки Intomodesma sp., захороненный по напластованию; в - известковистые стяжения шаровидной формы; 2 - тонкогоризонтальнослоистые и слабо косослоистые песчаники; $\partial, e$, ж- песчаники яснопятнистые; 3 - песчаник массивный с интракластом аргиллита; $a-6, \partial-3-$ руч. Титан, $2-$ руч. Дружба, правые притоки р. Хурэн в ее верховьях 

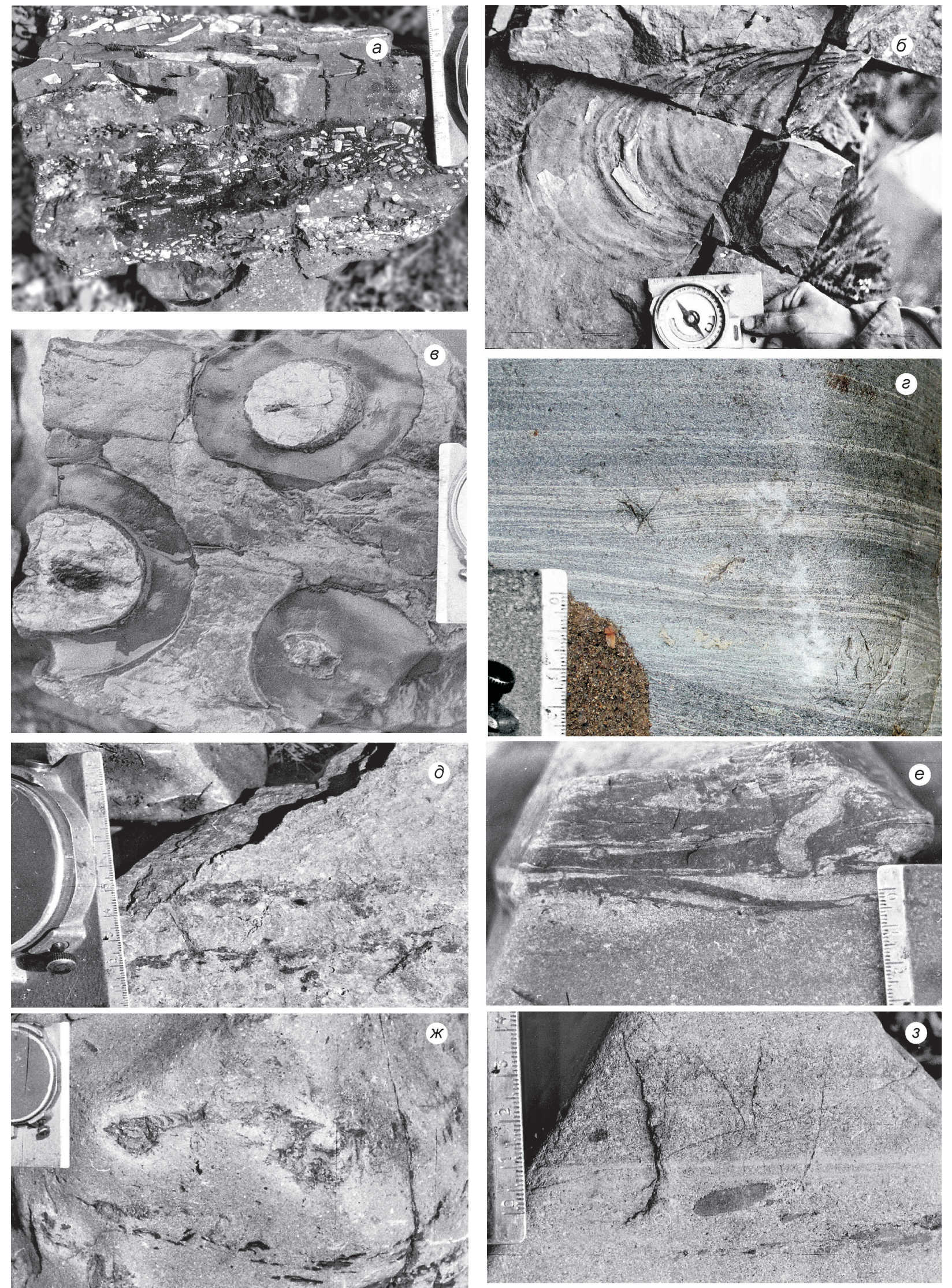

Fig. 2. Typical textures of the coastal sandstones facies group, Kulu formation: $a$ - shell rock composed from fragments of Inoceramus-like bivalve shells; $\sigma$ - imprint of a giant Inoceramus-like bivalve Intomodesma sp. buried by bedding; 8 - calcareous spherical concretions; 2 - thin horizontally laminated and weakly cross-stratified sandstones; $\partial, e$, $\varkappa$ - clearly spotted sandstones; 3 - massive sandstone with mudstone intraclast ; $a-6, \partial-3-$ Titan Creek, $2-$ Druzhba Creek, right tributaries of the Khuren River in its upper reaches 


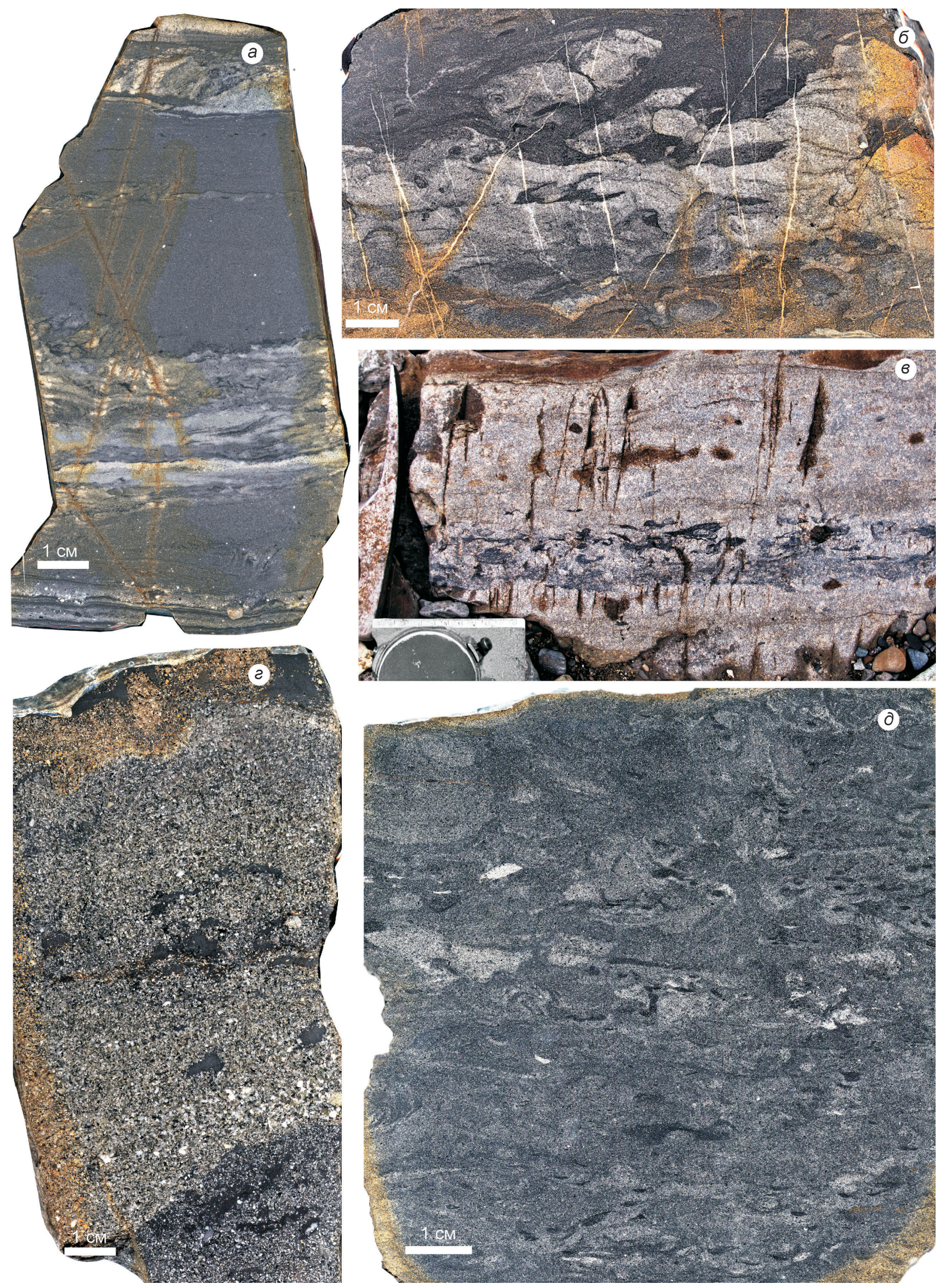

Puc. 3. Типовые текстуры группы фаций песчаников и алевролитов внутреннего шельфа, хурэнская свита: $a-2-$ переслаивание темно-серых мелкозернистых песчаников и песчанистых алевролитов, часто с неяснопятнистыми текстурами; $\partial$ - обильные мелкие (1-2 мм) фукоиды в неяснопятнистом алевролите; руч. Дружба, правый приток р. Хурэн в ее верховьях 
Здесь установлены почти все группы фауны, в том числе и характерные для открытых бассейнов с нормальной соленостью (брахиоподы, морские звезды и морские лилии). Захоронение как автохтонное, так и переотложенное, но чаще субавтохтонное.

Группа фаций песчаников и алевролитов преимущественно внутренней части шельфа. Типична для хурэнской свиты внутренней части восточной периферии Охотского бассейна. Характерные литотипы - отчетливо пластовое переслаивание темно-серых мелкозернистых песчаников и песчанистых алевролитов, часто с неяснопятнистыми текстурами (рис. $3, a-2$ ) и обильными мелкими (1-2 мм) фукоидами (рис. $3, \partial$ ). Довольно часто встречаются слои (десятки сантиметров) мелкозернистых серых известковистых песчаников. От предыдущей группы фаций отличается отсутствием обратной градационной слоистости, прослоев гравелитов и конгломератов, присутствием пачек (40-60 м) цикличного чередования песчаников, алевролитов и аргиллитов.

Остатки фауны обычно многочисленны и разнообразны, нередко встречаются в больших количествах, образуя ракушечники (двустворки рода Kolymia); окаменелости представлены почти всеми группами, в том числе организмами-индикаторами нормальной солености (аммоно-идеи, брахиоподы, морские лилии и морские бутоны). Захоронение их обычно автохтонное или субавтохтонное, но иногда может быть и переотложенным.

Группа фаций алевролитов внешней части шельфа характерактеризует беглинскую свиту внутренней части восточной периферии Охотского бассейна. Для этих отложений типичны углистые и алевритовые аргиллиты, а также глинистые кварцево-полевошпатовые алевролиты. Слоистость, как правило, неясная либо отсутствует. Очень характерны неяснопятнистые текстуры (рис. 4, $а$, б), образовавшиеся за счет пе- реработки осадка илоедами. Такие текстуры, по С. В. Максимовой (1984), наиболее часто встречаются в обстановках внешней части шельфа. Остатки фауны представлены скоплениями преимущественно относительно мелководных биссусноприкрепляющихся форм (двустворки родов Kolymia и Cyrtokolymia).

Группа фаций турбидитов типична для дружбинской и титанской свит внешней части восточной периферии Охотского бассейна и может быть разделена на фации проксимальных (песчаниковых) и дистальных (глинистых) турбидитов. Характерны выдержанная цикличность с контрастно проявленными в обнажениях слоевыми швами в подошве циклита (рис. 4, в, г) и почти полное отсутствие остатков ископаемой фауны.

Проксимальные турбидиты распространены относительно ограниченно. Для фации типичны контрастная цикличность трех порядков и градационная слоистость. Облик циклитов первого порядка (элементарных циклитов) часто соответствует классическому описанию цикла Боумы (рис. $4, e$ ). В большинстве случаев циклит отчетливо делится на три интервала. Первый интервал представлен градационным переходом от песчаника (иногда с гравием и единичными гальками) к алевролиту. Обычно его мощность не превышает $1 \mathrm{~cm}$, очень редко достигая $10 \mathrm{~cm}$. В подошве обычно наблюдаются микроразмывы, заполненные наиболее крупными зернами. Второй интервал сложен алевролитами с текстурами горизонтальной слоистости в основании, сменяющимися текстурами косой слоистости и затем вновь алевритами с горизонтальной слоистостью, нарушенной ходами илоедов. Выше следует постепенный переход к третьему интервалу - тонкоотмученному аргиллиту. Мощность циклита первого порядка обычно составляет 25-30 см.

Циклит второго порядка образован слоем песчаника мощностью 10-20 см, перекрытым одним или несколькими элементарными циклитами.

Fig. 3. Typical textures of sandstones and siltstones of the inner shelf facies, Khuren Formation: $a-2-$ interbedding of dark-gray fine-grain sandstones and sandy siltstones, often with indistinctly spotted textures; $\partial$-abundant small (1-2 mm) fucoids in indistinctly spotted siltstone; Druzhba Creek, right tributary of the Khuren River in its upper reaches

Puc. 4. Типовые структуры и текстуры двух групп фаций: алевролитов внешней части шельфа: $a-$ неясная пятнистость в алевролите, $\sigma$ - неясная пятнистость с наложенной структурой микрооползания осадка; шлифы, без анализатора, беглинская свита, руч. Беглый, правый приток р. Хурэн, и группы фаций турбидитов: 8 - отчетливая пластовая отдельность благодаря контрастной цикличности; 2 - характерная цикличность первого порядка, контраст для наглядности усилен, $\partial$ - складка оползания в глинистом слое турбидитов, $e-$ типичные текстуры элементарного циклита; титанская свита, руч. Титан, правый приток р. Хурэн

Fig. 4. Typical structures and textures of two facial groups: siltstones of the outer shelf: $a$-indistinctly spotted textures in siltstone, $\sigma$ - indistinct spotting with the superimposed sediment microslumping structure; thin sections, no analyzer, Begly Formation, Begly Creek, right tributary of the Khuren River, and groups of turbidite facies: 8 - distinct bedding due to contrasting cyclicity; 2 - characteristic cyclicity of the first order, contrast increased for clarity, $\partial-$ slump fold in a clay layer of turbidites, $e$ - typical textures of elementary cyclite; Titan Formation, Titan Creek, right tributary of the Khuren River 


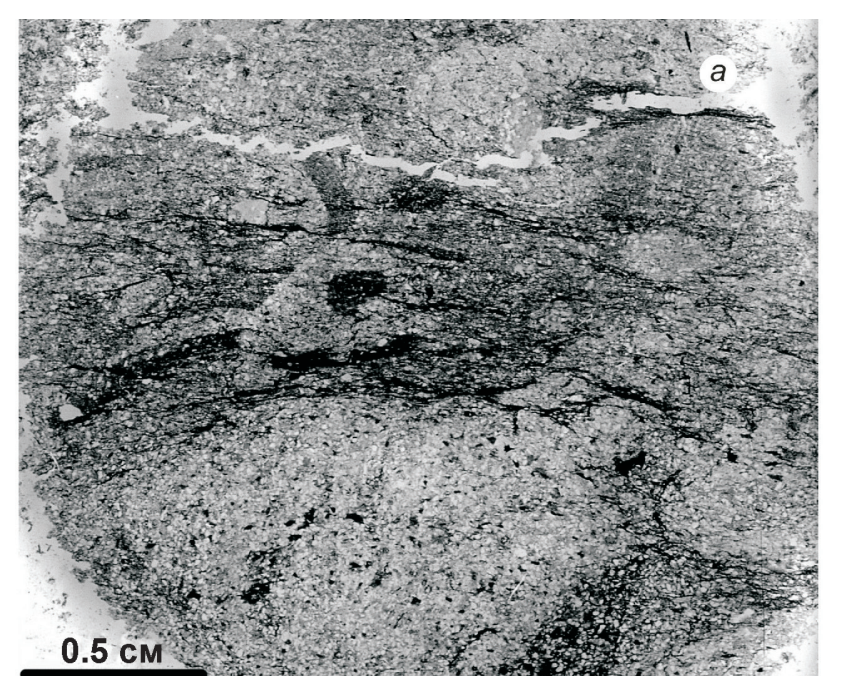

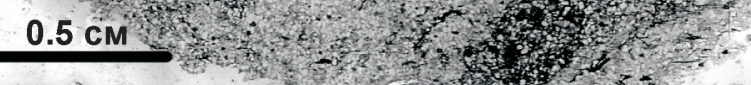
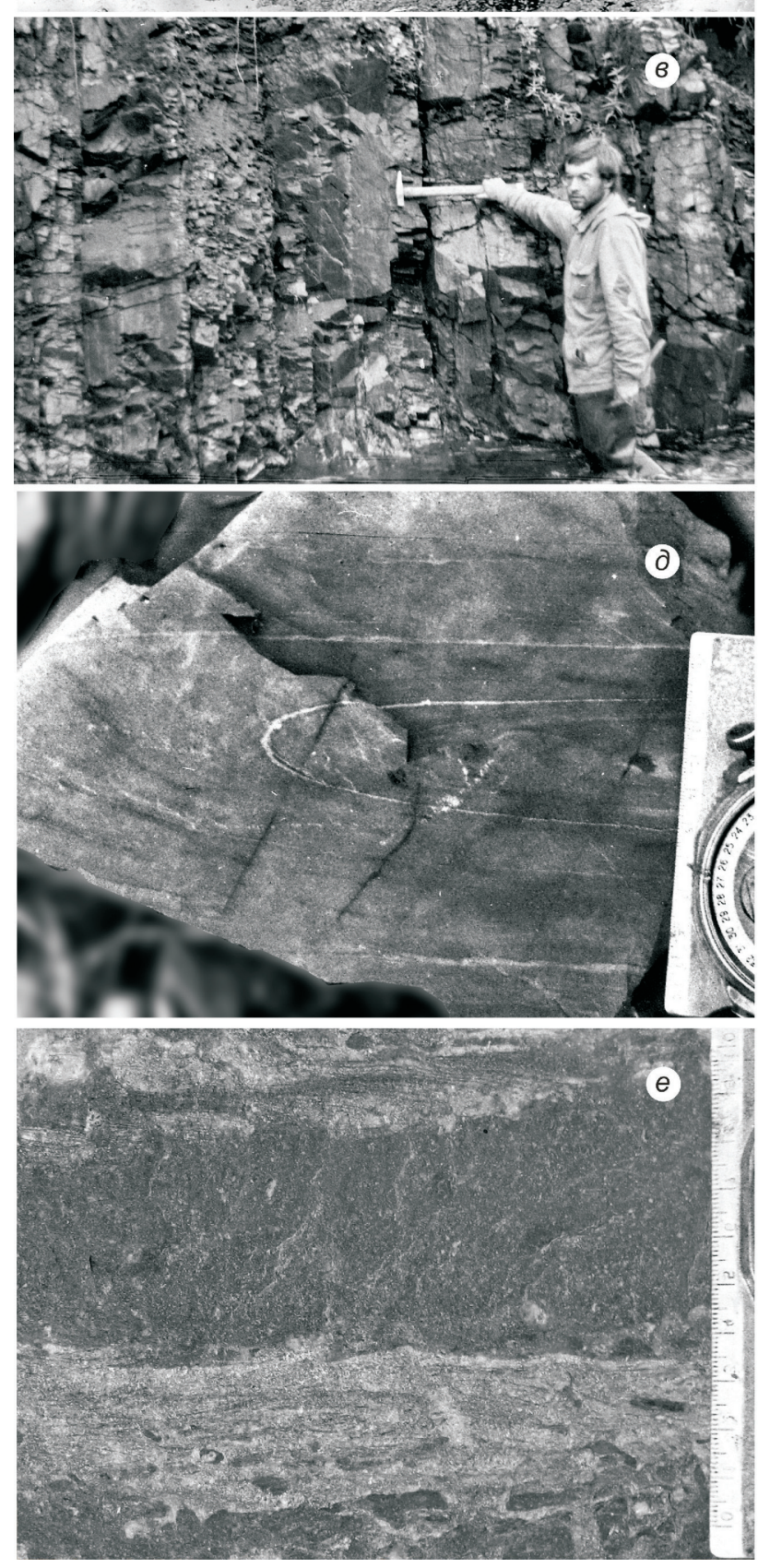
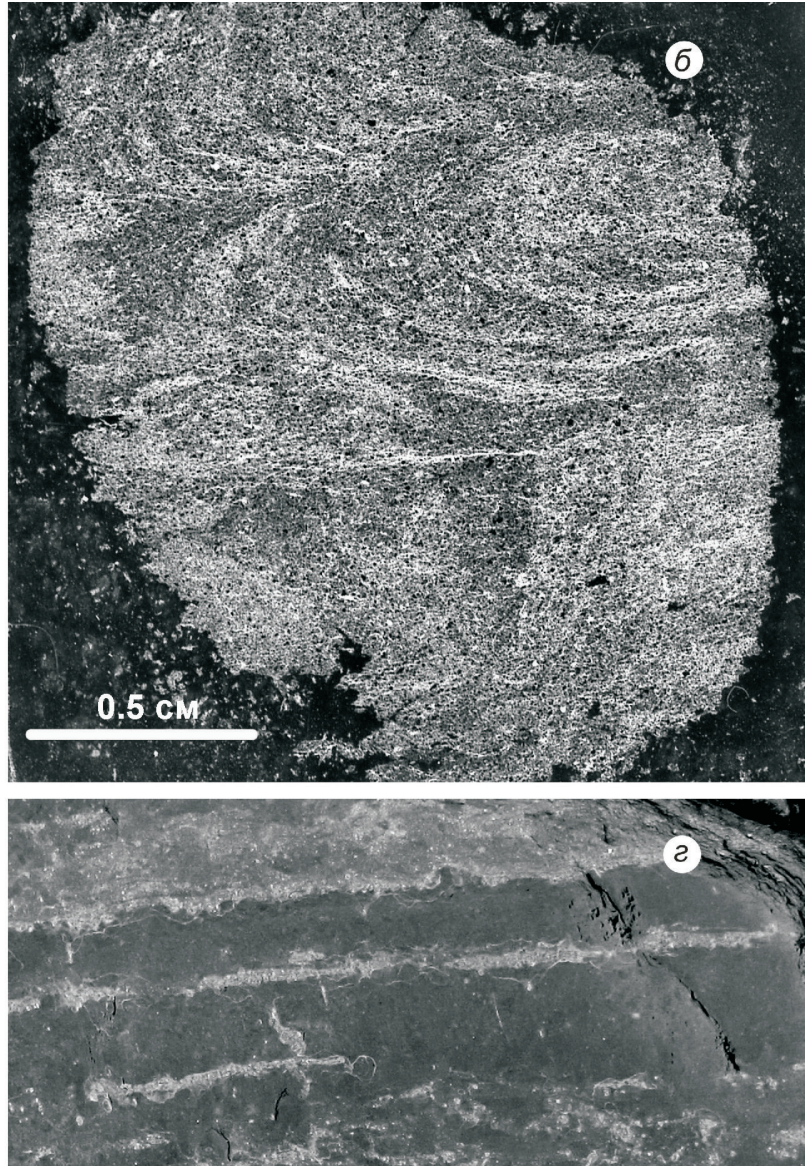

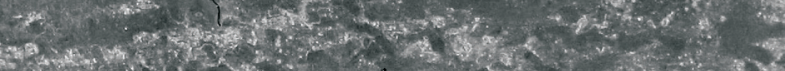

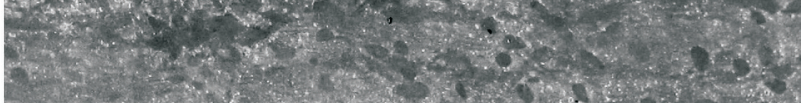

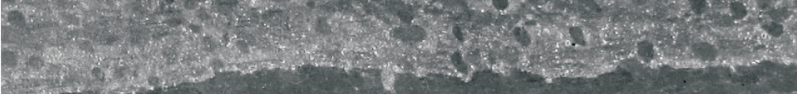
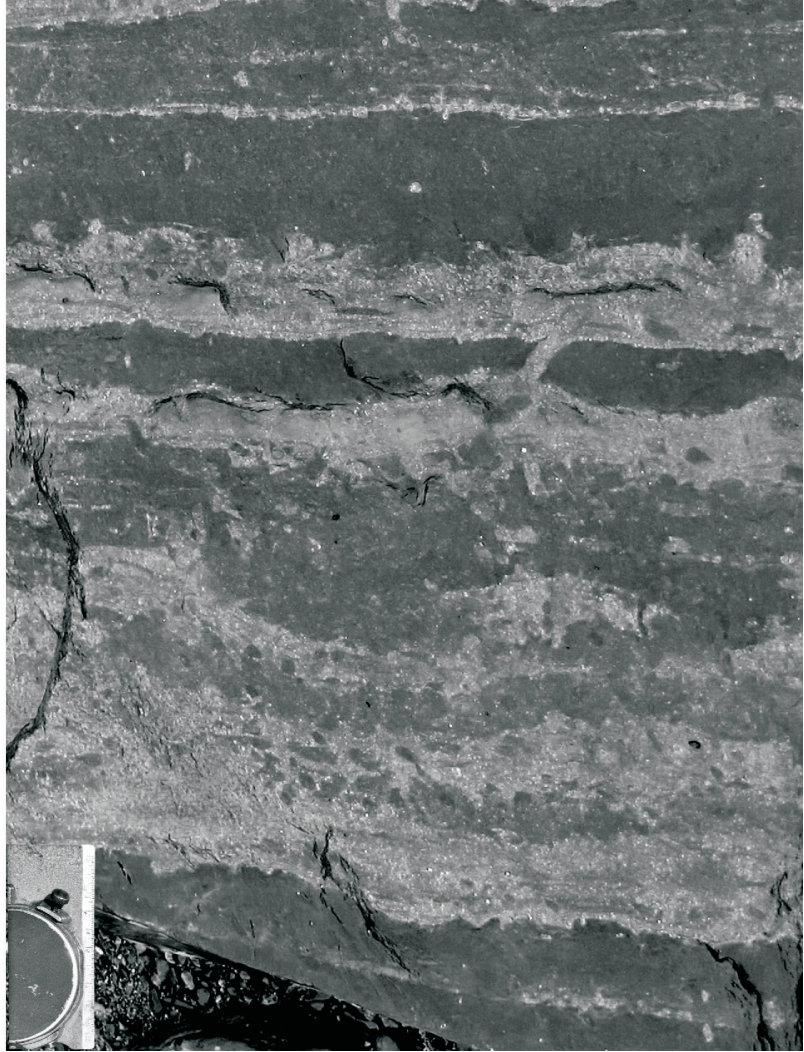

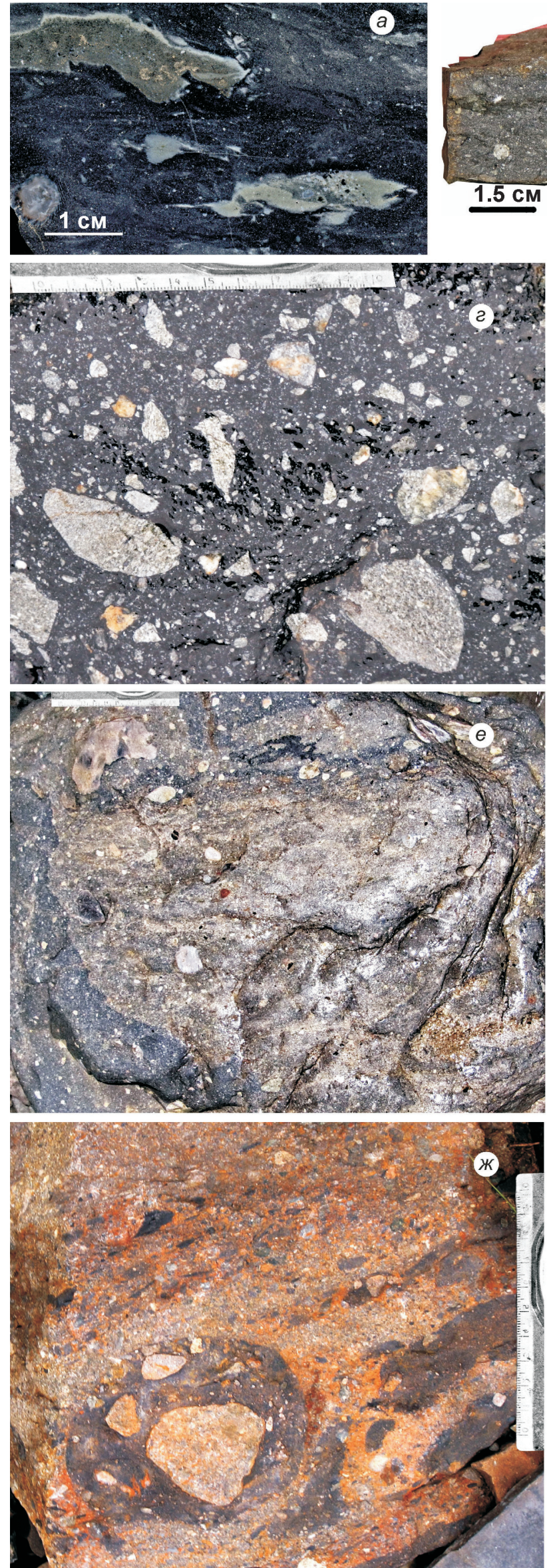
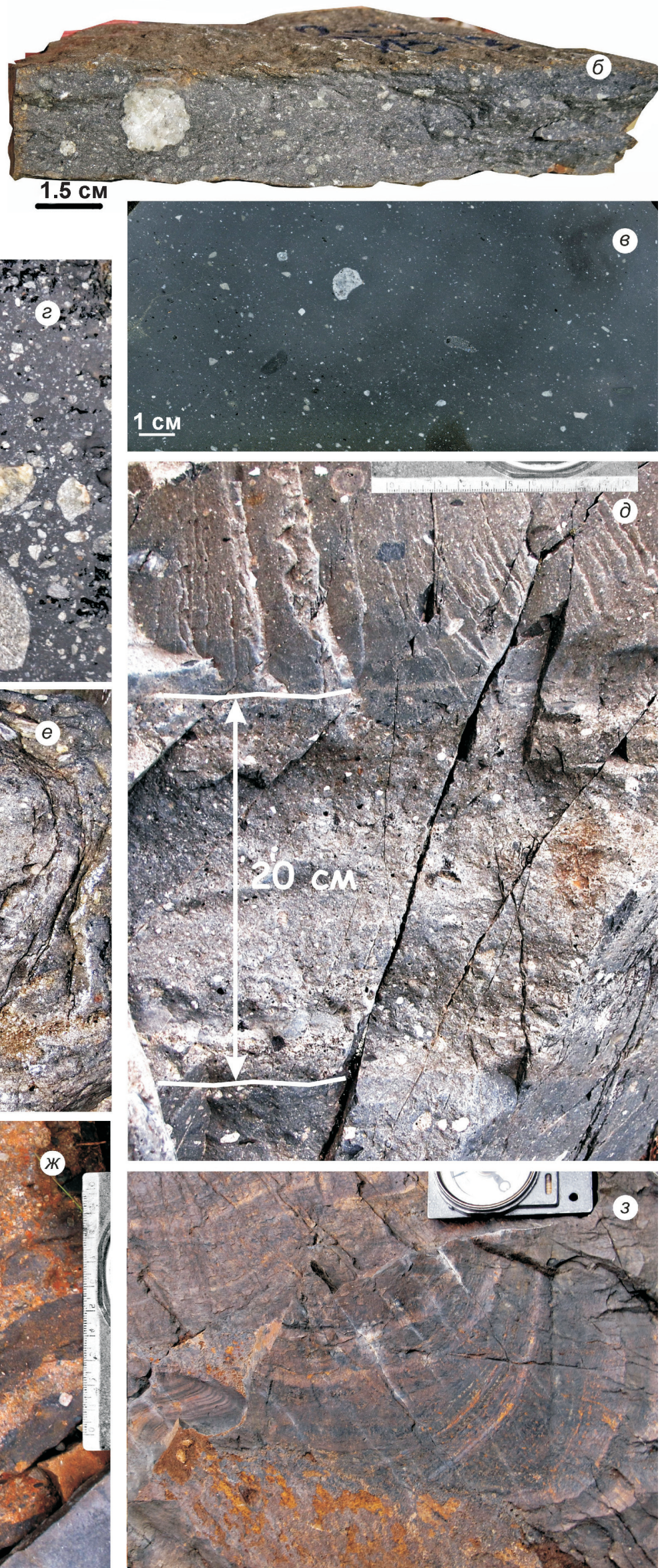
Puc. 5. Типовые текстуры группы фаций потоков разжиженного вулканогенно-осадочного материала: $a-$ деформации слоя пепловых туфов среднего состава (светлое) в массивных диамиктитах (характеризует подвижность матрикса диамиктитов в ходе диагенеза); $\sigma$ - серый дебрит с песчано-гравийной структурой и единичными включениями мелкогалечной размерности (видны свежий скол и бурая поверхность выветривания); в - темно-серый диамиктит, в котором включения гравийной и галечной размерности редки (пришлифовка); 2 - диамиктит, насыщенный включениями галечной размерности различной «окатанности»; $\partial$ - горизонтальный слой серого дебрита мощностью 20 см (центральная часть рисунка), кровля и подошва слоя отмечены белыми линиями в темно-сером (сером с поверхности выветривания) диамиктите (верх и низ рисунка); $e-$ слой серого дебрита (центр рисунка) в темно-сером диамиктите (по краям), смятый в результате оползания слабо диагенезированного осадка (в дебрите видны включения галечной размерности вулканического происхождения с заливчатыми и лапчатыми краями); ж-серые (рыжевато-серые с поверхности выветривания) дебриты с гравийной структурой, рассеянными включениями мелкогалечной размерности, интракластами и закатышами диамиктитов (темно-серое); з - пакет тонкого переслаивания алевролитов и аргиллитов фации глинистых потоков, смятый при оползании слабо диагенезированного осадка; $a, \sigma, z-e-$ руч. Дружба, правый приток р. Хурэн в ее верховьях; в, ж, з - атканская свита, истоки р. Хурэн

Fig. 5. Typical textures of the facial group of liquefied volcanic-sedimentary material flows: $a$ - deformations of the layer of medium ash (light) in massive diamictites (characterize mobility of the diamictite matrix in diagenesis); $\sigma$ - gray debrite with sand-gravel structure and single inclusions of small-pebble size (fresh split and brown weathering surface are visible); $в$ - dark-gray diamictite with rare gravel- and pebble-size inclusions (polished surface); 2 - diamictite, saturated with pebble-size inclusions with various degrees of "roundness"; $\partial-20 \mathrm{~cm}$ thick horizontal layer of gray debrite (central part of the picture), the layer roof and bottom marked with white lines in dark gray (gray from the weathering surface) diamictite (top and bottom of the picture); $e-$ layer of gray debrite (center of the picture) in dark-gray diamictite (at the edges), crumpled by the landslide of poorly diagenesized sediment (pebble-size volcanic inclusions with embayment and crow edges are visible in the debrite); $\varkappa$ - gray (reddish-gray from the weathering surface) debrites with gravel structure, scattered small pebble-size inclusions, intraclasts, and rounded diamictite inclusions (dark-gray); 3 - package of siltstones finely interbedding with mudstones of the clay flow facies, crumpled into folds during the landslide of weakly diagenesized sediment;

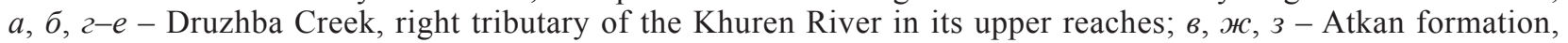
sources of the Huren River

Его мощность, как правило, около 1 м. Циклит третьего порядка представляет собой сочетание двух пакетов: пакета, состоящего из нескольких циклитов второго порядка (общей мощностью обычно 5-8 м), и пакета темно-серого аргиллита с алевритистой примесью и с тонкой горизонтальной слоистостью мощностью 10-20 м.

Дистальные турбидиты распространены наиболее широко и встречаются на различных интервалах разреза указанных свит. Основное отличие от проксимальных турбидитов - существенно меньшее количество песчаного и более грубого материала, а также цикличность одного порядка. Типично присутствие лишь маломощных (12 см) элементарных циклитов с градационной слоистостью. Характерны небольшие (первые сантиметры) складки оползания пакетов переслаивания аргиллита и алевролита (рис. $4, \partial)$.

Группа фаций потоков разжиженного осадочного материала включает в себя фации дебритов, грейнитов (зерновых потоков) и собственно глинистых потоков. Породы этой группы фаций типичны, главным образом, для атканской свиты, широко распространенной на северовосточной периферии изученного бассейна.

Потоки с крупныли частицами (дебриты) представлены двумя основными разновидностями - собственно дебритами и диамиктитами.
Первые встречаются относительно редко и образуют слои мощностью 0.2-3 м (рис. 5, $6, \partial, e)$ и пачки до 20 м мощности гравийных и мелкогалечных конгломератов и конгломерато-брекчий. Вторые распространены более широко (особенно на северо-восточной периферии Охотского бассейна, где они слагают атканскую свиту мощностью около 500 м (Бяков, Ведерников, 1990; Isbell et al., 2016). Типичные диамиктиты - породы массивной текстуры (рис. 5, в, 2), обычно образующие мощные пачки (до 80 м и более) и характеризующиеся присутствием в неслоистом или неяснослоистом матриксе рассеянного материала различной окатанности - от песчаной до галечной размерности (от 5-10 до 30-40\%). Матрикс, как правило, сильно рассланцован и в целом представляет собой темно-серую серицитизированную алеврито-глинистую массу, участками переходящую в микрофельзитовый агрегат с реликтовой витрокластической структурой. Рассеянный материал песчаной и более крупной размерности представлен угловатыми и округлыми обломками преимущественно эффузивов среднего состава щелочного ряда. Встречаются обломки (от 0.2-0.4 до 20 мм) пемзы с «рваными» краями, нередко с флюидальной структурой, при скрещенных николях сливающиеся со стекловатой массой матрикса, часто имеющие неправиль- 
ную «разлапистую» форму (Бяков и др., 2010; Isbell et al., 2016). Иногда в породах встречаются очень редкие остатки фауны, представленной, в основном, гастроподами; реже встречаются криноидеи, брахиоподы и двустворчатые моллюски. Часть из них, вероятно, переотложена из более мелководных, но одновозрастных обстановок осадконакопления.

Зерновые потоки (грейниты) представлены слоями (от первых десятков сантиметров до первых метров) массивных и плитчатых мелко-, среднезернистых песчаников. Состав обломков - преимущественно эффузивы среднего состава щелочного ряда и плагиоклаз. Иногда в песчаниках встречается примесь зерен гравийной размерности, состоящих из вулканического стекла и пемзы; довольно часто, особенно в подошве, наблюдаются интракласты черных аргиллитов, подстилающих эти песчаники.

Глинистые потоки (потоки тонкого илистого материала, по А. П. Лисицыну, 1988), также достаточно широко распространены. Как отмечает А. П. Лисицын (1988. С. 134), в Атлантическом океане ныне ими покрыто около $40 \%$ основания континентального склона. Характерна оползневая складчатость (см. рис. 5, 3). По текстурным особенностям фация глинистых потоков сходна с дистальными турбидитами, отличаясь отсутствием градационной и косой слоистости и меньшими мощностями слоев (около 1 см). По латерали мощности слоев и их песчанистость в основании циклита может несколько увеличиваться. Поскольку движение материала в таких потоках ламинарное, его дифференциации по крупности не происходит.

\section{ЗАКЛЮЧЕНИЕ}

Таким образом, в рассматриваемой статье нами впервые монографически описаны и проиллюстрированы основные пермские фации восточной периферии Охотского седиментационного бассейна. Установлены пять основных групп фаций: прибрежных песчаников, песчаников и алевролитов внутренней части шельфа, алевролитов внешней части шельфа, турбидитов и потоков разжиженного осадочного материала. Эти фации отражают последовательное изменение обстановок осадконакопления от мелководья к глубоководным частям бассейна.

Выделенные группы фаций позволяют проводить на новой основе литолого-фациальные реконструкции и способствуют более осмысленному пониманию сложных процессов терригенновулканогенного осадконакопления в пределах активной окраины Северо-Востока Азии.
Исследования поддержаны РФФИ, проект № 1705-00109.

Авторы выражают благодарность рецензентам за высказанные замечания и пожелания, способствовавшие улучшению текста статьи.

\section{ЛИТЕРАТУРА}

Бяков А. С. Биостратиграфия пермских отложений Северного Приохотья (Северо-Восток Азии) // Стратиграфия. Геол. корреляция. 2007. Т. 15, № 2. С. 4771.

Бяков А. С., Прокопьев А. В., Кутьгии Р. В. и др. Геодинамические обстановки формирования пермских седиментационных бассейнов Верхояно-Колымской складчатой области // Отечественная геология. 2005. № 5. C. $81-85$.

Бяков $A . \quad C$. Некоторые вопросы структурнофациального районирования и стратиграфии пермских отложений северо-восточного обрамления Охотского массива // Проблемы геологии и металлогении Северо-Востока Азии на рубеже тысячелетий : в 3-х т. Т. 1. Региональная геология, петрология и геофизика : Материалы XI сес. Сев.-Вост. отд. ВМО. Магадан : СВКНИИ ДВО РАН, 2001. С. 14-18.

Бяков А. С., Шпикерман В. И., Ведерников И. Л., Толмачева E. В. Первые результаты U-Pb SIMS датирования цирконов из вучапинских (верхняя пермь) отложений Северо-Востока России: значение для межрегиональных корреляций // Стратиграфия. Геол. корреляция. 2017. Т. 25, № 3. С. 19-28.

Бяков А. С., Ведерников И. Л., Акинин В. В. Пермские диамиктиты Северо-Востока Азии и их вероятное происхождение // Вестник СВНЦ ДВО РАН. 2010. № 1. С. 14-24.

Бяков А. С., Ведерников И. Л. Стратиграфия пермских отложений северо-восточного обрамления Охотского массива, центральной и юго-восточной частей Аян-Юряхского антиклинория : препринт. Магадан : СВКНИИ ДВО АН СССР, 1990. 69 с.

Лисищын А. П. Лавинная седиментация и перерывы в осадконакоплении в морях и океанах. М. : Наука, $1988.310 \mathrm{c}$.

Максимова С. В. Очерки по прикладной палеоэкологии. М. : Наука, 1984. 94 с.

Селли Р. К. Древние обстановки осадконакопления. М. : Недра, 1989. 294 с.

Умитбаев Р. Б. Стратиграфия верхнепалеозойских отложений центральной части Охотского срединного массива // Уч. зап. НИИГА. Сер. палеонт. и биостр. Л. : НИИГА, 1963. Вып. 2. С. 5-15.

Япаскурт О. В. Литогенез и полезные ископаемые миогеосинклиналей. М. : Недра, 1992. 224 с.

Davydov V. I., Biakov A. S., Schmitz M. D., Silantiev $V$. $V$. Radioisotopic calibration of the Guadalupian Series: review and updates // Earth-Science Reviews. 2018. Vol. 176. P. 222-240.

Isbell J. L., Biakov A. S., Vedernikov I. L. et al. Permian diamictites in Northeastern Asia: Their significance concerning the bipolarity of the late Paleozoic ice age // Ibid. 2016. Vol. 154. P. 279-300. 


\title{
PERMIAN MARINE FACIES OF THE EASTERN PERIPHERY OF THE OKHOTSK SEDIMENTARY BASIN (North-East Asia)
}

\author{
A. S. Biakov ${ }^{1,2}$, I. L. Vedernikov ${ }^{1}$

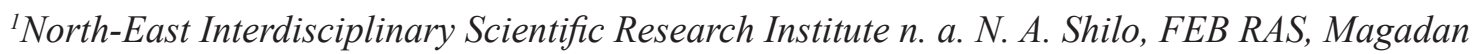 \\ ${ }^{2}$ North-Eastern State University, Magadan
}

In the Permian section of the eastern periphery of the Okhotsk sedimentary basin (North-East Asia), five main groups of facies have been identified: coastal sandstones, sandstones and siltstones of the inner part of the shelf, siltstones of the external part of the shelf, turbidites, and flows of liquefied sedimentary material. The turbidite facies are divided into facies of proximal (sandy) and distal (clayly) turbidites. The flows of liquefied sedimentary material are divided into facies of grainites, debrites, and clay flows proper. The first three groups of facies characterize relatively shallow (shelf) sedimentation environments while the last two correspond to the deeper conditions of the continental slope and its foot. Photos of the most typical textures are given.

Keywords: facies, eastern periphery of the Okhotsk sedimentary basin, Permian, North-East Asia.

\section{REFERENCES}

Biakov, A. S., 2001, Some Questions of StructuralFacies Zoning and Stratigraphy of Permian Deposits of the North-Eastern Framing of the Okhotsk Massif, Problems of Geology and Metallogeny of the Northeastern Asia at the Edge of the Millennia : Regional Geology, Petrology, and Geophysics : Proceedings of the XI ses. of NEB AMS, Magadan, NEISRI FEB RAS, 1, 14-18 [In Russian].

Biakov, A. S., 2007, Biostratigraphy of Permian Deposits in Northern Priokhotye (Northeast Asia), Stratigraphy and Geological Correlation, 15, 2, 161-184 [In Russian].

Biakov, A. S.; Prokopiev, A.V.; Kutygin, R. V.; Vedernikov, I. L.; Budnikov, I. V., 2005, Geodynamic Settings of Permian Sedimentary Basins Formation in the Verkhoyansk-Kolyma Folded Area, Otechestvennaya Geo-logiya, 5, 81-84 [In Russian].

Biakov, A. S.; Shpikerman, V.I.; Vedernikov, I. L.; Tolmacheva, E. V., 2017, The First Results of U-Pb SIMS Age Datings of Zircons from Upper Permian Vuchapin Deposits of Russia's North-East : Significance for Interregional Correlations, Stratigraphy and Geological Correlation, 25, 3, 256-264.

Biakov, A. S.; Vedernikov, I. L., 1990, Stratigraphy of Permian Deposits of the North-Eastern Framing of the Okhotsk Massif, Central and South-Eastern Parts of the Ayan-Yuryakh Anticlinorium, Preprint, Magadan, SVKNII DVO AN USSR [In Russian].
Biakov, A. S.; Vedernikov, I. L.; Akinin, V. V., 2010, Permian Diamictites of Northeast Asia and Their Probable Origin, Vestnik NESC FEB RAS, 1, 14-24 [In Russian].

Davydov, V. I.; Biakov, A. S.; Schmitz, M. D.; Silantiev, V. V., 2018, Radioisotopic Calibration of the Guadalupian Series: Review and Updates, Earth-Science Reviews, 176, 222-240.

Isbell, J. L.; Biakov, A. S.; Vedernikov, I. L.; Davydov, V. I.; Gulbranson, E. L.; Fedorchuk, N. D., 2016, Permian Diamictites in Northeastern Asia: Their Significance Concerning the Bipolarity of the Late Paleozoic Ice Age, Ibid., 154, 279-300.

Lisitsyn, A. P., 1988, Avalanche Sedimentation and Breaks in Sedimentation in Seas and Oceans, Moscow, Nauka Publishers [In Russian].

Maksimova, S. V., 1984, Essays on Applied Paleoecology, Moscow, Nauka Publishers [In Russian].

Selli, R. K., 1989, Ancient Sedimentary Settings, Moscow, Nedra [In Russian].

Umitbaev, R. B., 1963, Stratigraphy of Upper Paleozoic Deposits in the Central Part of the Okhotsk Middle Massif, Uchyoniye Zapiski NIIGA, Seriya Paleontologya $i$ Biostratigrafiya, Leningrad, NIIGA, 2, 5-15 [In Russian].

Yapaskurt, O. V., 1992, Lithogenesis and Mineral Resources of Miogeosynclines, Moscow, Nedra [In Russian]. 